\title{
Immigrant health workers in Chile: is there a Latin American "brain drain"?
}

\author{
Baltica Cabieses ${ }^{1}$ and Helena Tunstall ${ }^{2}$
}

Suggested citation Cabieses B, Tunstall H. Immigrant health workers in Chile: is there a Latin American "brain drain"? Rev Panam Salud Publica. 2012;32(2):161-7.

ABSTRACT Most research on the phenomenon of "brain drain" (one-way flow of highly skilled/educated individuals) has focused on movement between the least developed and most highly developed countries. Therefore, the significance of patterns of migration to middle-income countries such as those in Latin America is less clear. The aim of this study was to outline key features of international health worker "brain drain" to Chile to promote discussion and further research on this phenomenon as it pertains to the Latin American region. The study compared immigrant health workers living in Chile to both Chilean-born health workers and other immigrants living in Chile using a qualitative nationwide dataset (the results of Chile's 2009 National Socioeconomic Characterization Survey). Demographic, socioeconomic, and health-related variables were included in the analyses, which were weighted by population to obtain nationally representative estimates.

In 2009, immigrant health workers represented $2.2 \%$ of all health personnel and $2.6 \%$ of all resident immigrants in the country. While most immigrant health workers had a universitylevel education, about $25 \%$ had only a high school-level education or less.

There was no statistically significant difference between the distribution of immigrant health workers' household income and that of Chilean-born health workers. A significantly higher proportion of the immigrant group reported no entitlement to health care provision. While the results of this study do not indicate a significant international health worker "brain drain" to Chile, they do suggest distinctive patterns of migration within the Latin American region. Future studies in Chile could confirm the validity of these results, using a larger sample of immigrant health workers.

Key words Health personnel; migration; Latin America; Chile.

The phenomenon known as "brain drain" has been defined as the international recruitment and migration of high skilled workers, especially health workers, from less advantaged countries to more advantaged ones $(1,2)$. An increas-

\footnotetext{
Universidad del Desarrollo, Santiago, Chile. Send correspondence to: Baltica Cabieses, email: bcabieses@udd.cl

2 Department of Geography, University of Edinburgh, Scotland, United Kingdom.
}

ing number of medical doctors, nurses, and other health workers have been moving across national borders to pursue new opportunities and better career prospects (3). In 2006, in the United Kingdom, about one in three physicians in the National Health Service were from another country (3), and there were more nurses from Malawi working in Manchester alone than there were in Malawi (4).

Worldwide, the rate of "brain drain" has risen in recent decades (5). Research suggests a large number of less developed countries are affected by this phenomenon, including the Philippines and countries from sub-Saharan Africa (3). A loss of skilled human resources has also been reported in Latin America as workers travel abroad seeking a better life (3). Research by Özden (6) found that the extent of migration of workers with at least a college degree is extremely high for many countries in the region. This is especially true for some of the smaller 
and less developed countries that fail to establish adequate labor market opportunities for educated workers. As a consequence, college-educated workers are over-represented among the migrants from these countries compared to their overall share in the native population.

The loss of skilled health care staff in less developed countries is likely to have an extremely negative impact on those countries' health care system $(3,7)$. International debate has developed over whether the recruitment of health workers from developing countries by developed countries is ethically justifiable. In 2011, the World Health Organization (WHO) drafted the WHO Global Code of Practice on the International Recruitment of Health Personnel (8), a "groundbreaking instrument that marks the first time that WHO Member States have used the constitutional authority of the Organization to develop a non-binding code in 30 years" (8). This code-which establishes and promotes voluntary principles and practices for the ethical international recruitment of health personnel and the strengthening of health systems, and has been adopted by all 193 WHO member states-has created an urgent need to improve the available data on the "brain drain" of health personnel. As most research on "brain drain" has focused on the movement of skilled workers between the least and most highly developed countries, there is a particular need for data on patterns of health worker migration to middleincome countries such as those in Latin America.

In past decades, migrant destination countries have favored policies seeking to attract highly skilled workers from abroad. With the recent global economic crisis, however, these policies-and the dynamics of brain drain-may have changed. Cerna (9) recently explored this issue in five regions: Asia, Australasia, Europe, the Middle East, and North America. Her findings showed that with the onset of the crisis and increasing pressure to "protect" native-born workers from rising unemployment, many governments have introduced restrictions on highly skilled migration. The effect of the financial crisis has not been explored in relation to immigration to Chile, however, despite a relative increase in the immigration rate to this country in recent years (10).
According to the literature, Latin American intra-regional migration has increased significantly over the past three decades $(11,12)$. While both the educational background and employment prospects of international immigrants in this region vary according to the conditions and circumstances under which workers migrate, they tend to depend on the demand of the labor markets $(13,14)$. These variables shape the dynamics of the "brain drain" phenomenon in the Latin American region, including the migration of skilled health workers.

While significant research has been conducted on the overall "brain drain" in Latin America (6, 15-19), little evidence has been generated on skilled health workers (20), despite the growing and complex health needs of the Latin American population. Moreover, to the best of the current authors' knowledge, no prior study has focused specifically on international health worker "brain drain" to Chile. Chile has attracted increasing numbers of immigrants, and in 2006 more than $70 \%$ of them came from other Latin American countries-mostly Argentina, Bolivia, Ecuador, and Peru (10, 21). The socioeconomic characteristics of immigrants in Chile have changed in recent decades, with a relative decrease of highly educated people, a phenomenon that has been accompanied by a relative increase in the migration of Chilean-born people for study purposes, particularly at the university and postgraduate level (10). Although immigrants in Chile may be less educated than in the past, they continue to contribute to the economic development of the country. While a proportion of them make a direct contribution to health care services, the actual rates are difficult to estimate. Therefore, the volume of international health worker "brain drain" to Chile remains unknown. In addition, the characteristics of immigrant health workers in Chile have not been researched, so it is not clear whether they represent a relatively privileged or vulnerable group within the Chilean population.

The aim of this study was to outline key features of the "brain drain" of international health workers to Chile to promote discussion and further research on overall "brain drain" in Latin America. This article describes the volume of international health workers migrating to Chile ("brain drain") and their sociodemographic and health characteristics.

\section{MATERIALS AND METHODS}

To assess the volume and characteristics of immigrant health workers resident in Chile, this study compared that group to both Chilean-born health workers and other immigrants living in Chile. The only quantitative, nationwide dataset available in Chile for this purpose was the 2009 National Socioeconomic Characterization Survey (Encuesta de Caracterización Socio-Económica Nacional, CASEN). The CASEN survey is a large, anonymous, nationally representative household survey conducted every three years in Chile that aims to describe the socioeconomic and general health conditions of the Chilean population (22). Since 2006, the CASEN survey has covered migration status as well as other, more long-standing socioeconomic and health status variables. A detailed methodological explanation of this survey can be found elsewhere (23).

The 2009 CASEN dataset was downloaded by the authors following the approval of a request made through the survey's official Web site (www. mideplan.cl) in March 2011. For this study, health workers were defined using CASEN data collected in response to the question: "In what labor sector do you work?" Those who chose "Medicine, dentistry, and other health services" (out of 169 different categories) were included in the study analysis. It should be noted that a wide range of health workers, with variable levels of skills and education, fall into this category. Migrant status was defined based on the response to the question "Where did your mother live when you were born?" If survey participants chose the response "In a different country from Chile," they were categorized as "international immigrants" and compared to the other categories combined ("In a different county in Chile" and "In the same county in Chile"). To allow for broad exploration of the characteristics and living conditions of immigrant health workers in Chile, a wide range of variables were analyzed, including demographic (age, sex, urban/rural area of residence, region of country, self-reported ethnicity [any of the nine legally recognized aboriginal ethnic tribes in Chile], marital 
status, and country of origin); socioeconomic (education, household income [by quintile], type of occupation, employment status, and contractual status); and health-related (entitlement to health care provision, overall [self-perceived] health status, presence of disability, and mean number of health care contacts in past three months). It should be noted that the health care system in Chile is complex, comprising both public and private systems that have minimal interaction and collaboration. The public health care system covers about $70 \%$ of the population (mostly the sick and the elderly) while the private system, which includes about 150 different insurance plans, covers about $30 \%$ (24).

Descriptive and comparative analysis was conducted using STATA 10.0 (Stata Corporation, College Station, TX, USA). Due to the complex sampling strategy used in the survey, the results were weighted by population to ensure nationally representative estimates. Crude proportions and means were estimated, and chi-square tests were used to estimate differences between groups, based on $95 \%$ confidence intervals (CIs).

\section{RESULTS}

\section{Profile of resident immigrant health workers in Chile in 2009}

From the 246924 total participants who responded to the CASEN survey in 2009 (weighted population size = $16971378), 2225$ reported being health workers (weighted sample size $=258060$ ) and 1829 were international immigrants (weighted sample size $=209772$ ). Out of all health workers, 49 were international immigrants (weighted sample size = 5 554) and 2176 reported being Chileanborn (weighted sample size $=249301$ ) (Table 1). Therefore, in 2009, immigrant health workers represented $2.2 \%$ of all health personnel in Chile and $2.6 \%$ of all resident immigrants in the country. Just under half of all immigrant health workers came from Canada $(48.06 \%)$ and $45.24 \%$ originated from Latin America (Table 1). Among Latin American immigrants, Bolivia, Ecuador, and Mexico were the most common countries of origin reported for health workers, whereas among the total immigrant population in Chile, the most frequent cited ones were Argentina, Bolivia, and Peru (Table 1).
A comparison of different occupational groups indicated that immigrants in Chile were more over-represented versus the native-born population in certain occupations. For example, as shown in Table 2, there are significantly higher proportions of immigrants with contracts for managerial positions and in domestic service versus the Chileanborn population.

Compared to their Chilean-born counterparts, immigrant health workers living in Chile in 2009 were more likely to be younger, female, and married, with an ethnic background, and living in an urban area. However, no statistically significant differences were found between the two groups for these variables. There was a significantly higher proportion of immigrant health workers versus Chilean-born health workers in both the Santiago metropolitan area $(87.50 \%$ versus $57.63 \%, P<0.05)$ and the central area of the country, with a very weak presence in the rest of Chile (Table 1).

As shown in Table 2, there were no significant differences in the educational level of immigrant health workers versus Chilean-born health workers, and almost half of both groups had a universitylevel education $(45.86 \%$ and $49.87 \%$, respectively). However, a significant minority of immigrant health workers were low skilled and poorly educated, with about 25\% having only high school-level or less education.

A significantly lower proportion of health workers (both immigrant and Chilean-born) were in the poorest household income quintile compared to non-health workers in each of the populations under study $(P<0.05)$ (Table 2 ). There were no statistically significant differences in the distribution of immigrant health workers' household income versus that of Chilean-born health workers. Similar results were found when estimating the absolute mean household income per capita by quintile (shown in Table 2, in Chilean pesos) among immigrant health workers versus Chilean-born health workers. All immigrant health workers were employed at the time of the study, and a higher but a non-statistically significant proportion of them reported having a contract for a managerial position, working in the private sector, or being self-employed versus the Chilean-born health workers.
Immigrant health workers reported their overall self-perceived health status as "good/very good" at a slightly higher rate than their Chilean-born counterparts, but this difference was not statistically significant (Table 3). While no immigrant health workers reported having a disability, their overall mean number of "health care contacts in the past three months" was slightly higher than that of Chilean-born health workers $(P>0.05)$. In addition, a significantly higher proportion of immigrant health workers reported having no entitlement to health care provision compared to the Chileanborn health workers (50.94\% versus $1.72 \%$, $P<0.001)$. Among those who were entitled to health care services, a significantly lower proportion of immigrant health workers had access to the public health care system compared to their Chilean-born counterparts $(0.16 \%$ versus $5.26 \%, P<0.001$ ) (Table 3).

A comparison was also made between immigrant health workers and all immigrants living in Chile. Compared to the latter group, immigrant health workers were more likely to be of working age, and a currently active worker with a managerial contract, and to have a technical or university-level education, and a higher household income per capita. Immigrant health workers reported a significantly lower rate of public, free-ofcharge health insurance in Chile versus other sectors of the international immigrant population (Table 3 ).

\section{DISCUSSION}

Based on the 2009 CASEN survey results analyzed in this study, there is little evidence of an international health worker "brain drain" to Chile because 1) immigrant health workers represented a small proportion of the total populations of both health workers and immigrants residing in the country, and 2) the characteristics of the immigrant health worker population in 2009 did not meet the classic definition of the term (skilled people migrating from less to more developed countries). While the majority of immigrant health workers participating in the survey self-reported as highly educated, a significant minority did not, with slightly more than $25 \%$ reporting only a high school-level education or less. In addition, almost half came from a more developed country 
TABLE 1. Demographic characteristics of the general Chilean-born population, Chilean-born health workers, the international immigrant population overall, and immigrant health workers, according to the CASEN ${ }^{\mathrm{a}}$ survey, Chile, 2009b

\begin{tabular}{|c|c|c|c|c|}
\hline Demographic characteristic & $\begin{array}{c}\text { General Chilean-born } \\
\text { population } \\
\left(95 \% \mathrm{Cl}^{\mathrm{C}}\right)\end{array}$ & $\begin{array}{l}\text { Chilean-born } \\
\text { health workers } \\
(95 \% \mathrm{Cl})\end{array}$ & $\begin{array}{l}\text { General immigrant } \\
\text { population } \\
(95 \% \mathrm{Cl})\end{array}$ & $\begin{array}{l}\text { Immigrant } \\
\text { health workers } \\
(95 \% \mathrm{Cl})\end{array}$ \\
\hline Absolute population & 243740 & 2176 & 1829 & 49 \\
\hline Weighted population & 16620075 & 249301 & 209772 & 5554 \\
\hline \multicolumn{5}{|l|}{ Age $(\%)$} \\
\hline Male & $48.16(47.86-48.46)$ & $29.82(26.17-33.74)$ & $48.44(44.26-52.64)$ & $18.92(4.22-55.31)$ \\
\hline Female & $51.84(51.54-52.14)$ & $70.18(66.26-73.83)$ & $51.56(47.36-55.74)$ & 81.08 (44.69-95.78) \\
\hline Mean age & $34.22(34.03-34.41)$ & 40.72 (39.74-41.69) & 33.95 (31.62-36.28) & $32.34(23.01-41.65)$ \\
\hline \multicolumn{5}{|l|}{ Age group (years) $(\%)$} \\
\hline$<16$ & 23.90 (23.58-24.22) & $-^{d}$ & $14.60(10.46-20.02)$ & - \\
\hline $16-65$ & $65.42(65.10-65.75)$ & 97.54 (96.32-98.36) & 76.43 (71.46-80.78) & $97.84(80.76-99.80)$ \\
\hline$>65$ & 10.68 (10.43-10.93) & $2.46(1.64-3.68)$ & $8.96(6.63-12.01)$ & $2.16(0.20-19.24)$ \\
\hline \multicolumn{5}{|l|}{ Area of residence (\%) } \\
\hline Urban & 86.32 (85.95-86.68) & 95.19 (93.36-96.53) & 93.17 (89.92-95.43) & $98.16(91.62-99.62)$ \\
\hline Rural & $13.68(13.32-14.05)$ & $4.81(3.47-6.64)$ & $6.83(4.47-10.08)$ & $1.84(0.38-8.38)$ \\
\hline \multicolumn{5}{|l|}{ Region of country (\%) } \\
\hline \multicolumn{5}{|l|}{ Northern area } \\
\hline Arica and Parinacota (XV) & $1.06(0.93-1.21)$ & $0.71(0.42-1.19)$ & $2.91(2.04-4.26)$ & - \\
\hline Tarapacá (I) & $1.79(1.58-2.01)$ & $0.71(0.38-1.33)$ & $5.16(3.49-7.57)$ & $2.11(0.25-15.72)$ \\
\hline Antofagasta (II) & 3.37 (3.07-3.69) & $3.69(2.66-5.10)$ & $4.30(2.58-7.08)$ & - \\
\hline Atacama (III) & $1.66(1.46-1.90)$ & $0.77(0.49-1.21)$ & $0.96(0.37-2.48)$ & - \\
\hline Coquimbo (IV) & $4.23(3.99-4.49)$ & $2.05(1.15-3.62)$ & $1.41(0.55-3.58)$ & - \\
\hline \multicolumn{5}{|l|}{ Central area } \\
\hline Valparaíso (V) & $10.32(9.91-10.75)$ & $9.76(7.54-12.54)$ & $6.83(4.73-9.80)$ & $3.55(0.37-26.89)$ \\
\hline Santiago metropolitan area (RM/XIII) & $39.76(38.98-40.54)$ & $57.63(53.46-61.70)$ & $66.84(60.52-72.61)$ & $87.50(61.58-96.83)$ \\
\hline O'Higgins (VI) & $5.24(5.01-5.49)$ & $3.09(2.17-4.38)$ & $0.96(0.56-1.65)$ & $1.69(0.20-12.61)$ \\
\hline Maule (VII) & $5.99(5.72-6.27)$ & $3.27(2.46-4.34)$ & $1.48(0.60-3.62)$ & - \\
\hline Biobío (VIII) & $12.11(11.73-12.51)$ & $9.19(7.78-10.83)$ & $1.64(1.07-2.52)$ & $2.48(0.33-16.49)$ \\
\hline \multicolumn{5}{|l|}{ Southern area } \\
\hline Araucanía (IX) & $5.71(5.44-5.99)$ & $2.34(1.64-3.33)$ & $4.09(2.32-6.90)$ & - \\
\hline Los Lagos (X) & $4.93(4.67-5.20)$ & $3.09(2.27-4.20)$ & $1.90(1.27-2.85)$ & $1.71(0.31-8.81)$ \\
\hline Aisén (XI) & $0.62(0.56-0.68)$ & $0.77(0.50-1.16)$ & $0.37(0.21-0.66)$ & - \\
\hline Magallanes and Antártica Chilena (XII) & $0.95(0.80-1.12)$ & $1.24(0.62-2.44)$ & $0.53(0.28-1.01)$ & - \\
\hline Los Ríos (XIV) & $2.26(2.09-2.45)$ & $1.70(1.06-2.69)$ & $0.56(0.30-1.02)$ & $0.95(0.09-9.36)$ \\
\hline \multicolumn{5}{|l|}{ Marital status (\%) } \\
\hline Single & $50.35(50.05-50.65)$ & 33.34 (29.98-36.88) & 40.25 (34.99-45.74) & $16.19(2.40-60.23)$ \\
\hline Married & $40.65(4.43-4.73)$ & $53.46(49.39-57.48)$ & $53.99(48.66-59.24)$ & $81.98(39.16-96.98)$ \\
\hline Divorced & $4.58(4.43-4.57)$ & $11.25(9.12-13.80)$ & $2.96(2.06-4.24)$ & $1.84(0.24-12.54)$ \\
\hline Widow & $4.42(4.27-4.57)$ & $1.95(1.30-2.92)$ & $2.80(1.72-4.51)$ & - \\
\hline Has ethnic background (\%) & $6.86(6.59-7.14)$ & $3.49(2.49-4.88)$ & $7.10(5.04-9.91)$ & $10.80(1.65-46.69)$ \\
\hline \multicolumn{5}{|l|}{ Country of origine $(\%)$} \\
\hline Peru & - & - & 29.68 (22.1-38.59) & $3.35(0.37-24.43)$ \\
\hline Argentina & - & - & $23.12(17.62-29.73)$ & $3.96(0.74-18.55)$ \\
\hline Bolivia & - & - & 7.65 (4.83-11.92) & $7.74(0.80-46.60)$ \\
\hline Ecuador & - & - & $3.81(1.86-7.65)$ & $18.42(3.14-61.15)$ \\
\hline Colombia & - & - & $6.71(3.48-12.56)$ & $3.42(0.65-16.00)$ \\
\hline Canada & - & - & $1.96(0.53-6.97)$ & $48.06(9.05-89.59)$ \\
\hline Mexico & - & - & $1.91(0.71-5.03)$ & $8.35(0.81-50.29)$ \\
\hline
\end{tabular}

a National Socioeconomic Characterization Survey (Encuesta de caracterización Socio-Económica Nacional), Ministerio de Desarrollo Social, Chile (2009).

b Weighted by population to obtain nationally representative estimates.

c $\mathrm{Cl}$ : confidence interval.

d NA: not applicable.

e Selection of countries reporting the most data for overall immigrant and health worker immigrant populations.

(Canada), while the majority of the remainder came from other Latin American countries, only some of which are significantly less advantaged than Chile. This latter characteristic was an interesting and unexpected feature that illustrates the complexity of migration to Chile, which includes individuals from high-income, stable countries as well as those from lower-income countries with socioeconomic issues or political conflict, such as Bolivia, Ecuador, and Mexico.

While the results of the analysis did not support international health worker "brain drain" to Chile, they did suggest that immigrant health workers are a distinctive subset of both the health worker and international immigrant populations in Chile, with some significant differences in their socio-demographic and health profile. For example, immigrant health workers were more likely than other international immigrant groups to be highly educated (with a technical or university-level education) and less likely to fall into the poorest household income quintiles (although the latter difference was not statistically significant). In addition, most immigrant health personnel were not entitled to any health care service provision, as opposed to Chilean-born health workers. Finally, 
TABLE 2. Socioeconomic characteristics of the general Chilean-born population, Chilean-born health workers, the international immigrant population overall, and immigrant health workers, according to the CASEN ${ }^{\mathrm{a}}$ survey, Chile, 2009 ${ }^{\mathrm{b}}$

\begin{tabular}{|c|c|c|c|c|}
\hline Socioeconomic characteristic & $\begin{array}{c}\text { General Chilean-born } \\
\text { population } \\
\left(95 \% \mathrm{Cl}^{\mathrm{C}}\right)\end{array}$ & $\begin{array}{l}\text { Chilean-born } \\
\text { health workers } \\
(95 \% \mathrm{Cl})\end{array}$ & $\begin{array}{c}\text { General immigrant } \\
\text { population } \\
(95 \% \mathrm{Cl})\end{array}$ & $\begin{array}{l}\text { Immigrant } \\
\text { health workers } \\
(95 \% \mathrm{Cl})\end{array}$ \\
\hline \multicolumn{5}{|l|}{ Education } \\
\hline None & $7.62(7.43-7.81)$ & $0.31(0.10-0.93)$ & $3.12(1.85-5.43)$ & $0.16(0.04-0.69)$ \\
\hline Primary school & $33.89(33.51-34.82)$ & $4.53(3.48-5.87)$ & $20.05(14.52-27.03)$ & $4.35(3.16-5.97)$ \\
\hline High school & $31.37(30.96-31.78)$ & $21.93(19.05-25.11)$ & $30.69(25.64-36.25)$ & $22.57(18.93-26.58)$ \\
\hline Technical level & $11.84(11.57-12.11)$ & $23.36(20.61-26.36)$ & $10.34(8.03-13.23)$ & $27.06(23.16-31.35)$ \\
\hline University level & $15.28(14.84-15.73)$ & $49.87(45.50-54.24)$ & $35.79(29.09-43.09)$ & $45.86(40.07-51.76)$ \\
\hline \multicolumn{5}{|l|}{ Household income } \\
\hline Quintile 1 (poorest) & $15.13(14.67-15.60)$ & $2.81(1.97-4.00)$ & $15.53(15.07-16.01)$ & $3.92(2.49-6.13)$ \\
\hline Quintile 2 & $16.61(16.13-17.09)$ & $6.33(5.06-7.89)$ & $17.99(17.44-18.55)$ & $6.17(4.64-8.16)$ \\
\hline Quintile 3 & $18.37(17.85-18.90)$ & $11.88(9.98-14.08)$ & $19.70(19.09-2032)$ & $13.72(11.15-16.76)$ \\
\hline Quintile 4 & $20.58(20.03-21.14)$ & $21.80(19.05-24.84)$ & $21.42(20.76-22.10)$ & $24.67(20.87-28.90)$ \\
\hline Quintile 5 (wealthiest) & $29.31(28.56-30.07)$ & $57.17(53.02-61.22)$ & $25.36(24.57-26.16)$ & $51.52(45.79-57.29)$ \\
\hline \multicolumn{5}{|l|}{$\begin{array}{l}\text { Absolute mean household } \\
\text { income per capita }\end{array}$} \\
\hline Quintile 1 (poorest) & 148909 (147 216-150 603) & 164813 (138 646-190 980) & 148871 (146 969-150 772) & 159159 (120 029-199 161) \\
\hline Quintile 2 & 289783 (288 674-290 289) & 302059 (295 327-308 791) & 289746 (288 500-290 993) & 306622 (297 277-315 567) \\
\hline Quintile 3 & 435216 (433 726-436 707) & 453584 (447 284-459 883) & 435018 (433 403-436 633) & 450495 (441 783-459 207) \\
\hline Quintile 4 & 622333 (659 376-665 291) & 677536 (667 720-687 352) & 661028 (657 691-664 365) & 681915 (669 799-694 032) \\
\hline Quintile 5 (wealthiest) & 1909827 (1 823 217-1997 336) & 2259136 (1 $987725-2530546)$ & 1726358 (1 $654783-1797934)$ & 2046706 (1 672 902-2 420 509) \\
\hline Currently active worker & $44.87(44.49-45.25)$ & $94.49(91.94-96.27)$ & $58.08(52.39-63.56)$ & $100(-\mathrm{e})$ \\
\hline \multicolumn{5}{|l|}{ Type of occupation } \\
\hline Managerial position & $3.02(2.75-3.31)$ & $1.65(0.96-2.84)$ & $7.72(3.9514 .57-)$ & $3.38(0.32-27.54)$ \\
\hline Employee, private system & $60.78(60.14-61.42)$ & $9.54(7.26-12.43)$ & $54.13(47.36-60.75)$ & $14.73(2.80-50.84)$ \\
\hline Employee, public system & $11.07(10.06-11.55)$ & $42.90(38.38-47.54)$ & $8.28(4.91-13.44)$ & $24.34(5.07-65.98)$ \\
\hline Self-employed & $20.34(19.83-20.87)$ & $45.92(41.61-50.26)$ & $17.97(12.91-24.45)$ & $57.54(16.07-90.56)$ \\
\hline Employee, domestic service & $4.79(4.55-5.04)$ & - & $11.90(7.83-17.69)$ & - \\
\hline Has a contract & $23.16(22.85-23.48)$ & $76.86(73.29-80.09)$ & $30.58(25.51-36.18)$ & $81.89(44.98-96.15)$ \\
\hline
\end{tabular}

a National Socioeconomic Characterization Survey (Encuesta de caracterización Socio-Económica Nacional), Ministerio de Desarrollo Social, Chile (2009).

b Weighted by population to obtain nationally representative estimates.

${ }^{c} \mathrm{Cl}$ : confidence interval.

${ }^{d}$ In Chilean pesos (based on 2006 exchange rate of $530 \mathrm{CLP}=1$ USD).

e NA: not applicable.

TABLE 3. Health-related characteristics of the general Chilean-born population, Chilean-born health workers, the international immigrant population overall, and immigrant health workers, according to the CASEN ${ }^{\mathrm{a}}$ survey, Chile, 2009

\begin{tabular}{|c|c|c|c|c|}
\hline Health-related characteristic & $\begin{array}{c}\text { General Chilean-born } \\
\text { population } \\
\left(95 \% \mathrm{Cl}^{\mathrm{C}}\right)\end{array}$ & $\begin{array}{c}\text { Chilean-born } \\
\text { health workers } \\
(95 \% \mathrm{Cl})\end{array}$ & $\begin{array}{c}\text { General immigrant } \\
\text { population } \\
(95 \% \mathrm{Cl})\end{array}$ & $\begin{array}{c}\text { Immigrant } \\
\text { health workers } \\
(95 \% \mathrm{Cl})\end{array}$ \\
\hline \multicolumn{5}{|l|}{ Entitlement to health care provision } \\
\hline None & 3.49 (3.26-3.73) & $1.72(1.05-2.79)$ & $14.66(9.76-21.42)$ & $50.94(10.95-89.76)$ \\
\hline Public, free-of-charge & $32.66(32.12-33.20)$ & $5.26(4.18-6.60)$ & $20.68(16.86-25.10)$ & $0.16(0.05-1.70)$ \\
\hline Public, with co-payment & $48.90(48.28-49.52)$ & $56.81(52.07-61.43)$ & $40.84(33.75-48.33)$ & $18.76(4.17-55.05)$ \\
\hline Private & $13.19(12.59-13.80)$ & $34.25(29.36-39.50)$ & $21.95(16.40-28.74)$ & $30.14(6.48-72.87)$ \\
\hline Other/not stated & $1.77(1.64-1.91)$ & $1.96(1.26-2.97)$ & $1.88(1.12-3.15)$ & $-d$ \\
\hline \multicolumn{5}{|l|}{ Overall health status (self-perceived) } \\
\hline Very poor/poor & $7.29(7.06-7.52)$ & $3.54(2.55-4.88)$ & $3.22(2.14-4.80)$ & $1.54(0.14-14.64)$ \\
\hline Regular & $19.55(19.18-19.93)$ & $11.79(9.80-14.12)$ & $14.29(10.41-19.31)$ & $8.97(1.04-48.10)$ \\
\hline Good/very good & $73.16(72.72-73.59)$ & 84.67 (82.09-86.93) & $82.49(77.35-86.66)$ & $89.50(52.24-95.28)$ \\
\hline Has a disability & $7.55(7.35-7.76)$ & $2.51(1.72-3.65)$ & $3.41(2.21-5.22)$ & $-d$ \\
\hline $\begin{array}{l}\text { Mean number of health care contacts in } \\
\text { past } 3 \text { months }\end{array}$ & $1.90(1.85-1.94)$ & $1.87(1.61-2.13)$ & $1.83(1.30-2.35)$ & $1.92(1.58-2.25)$ \\
\hline
\end{tabular}

a National Socioeconomic Characterization Survey (Encuesta de caracterización Socio-Económica Nacional), Ministerio de Desarrollo Social, Chile (2009).

b Weighted by population to obtain nationally representative estimates.

${ }^{c} \mathrm{Cl}$ : confidence interval.

d NA: not applicable.

immigrant health workers were more likely to live in the central area of the country, including metropolitan Santiago, compared to the northern and southern areas, most likely due to the centralization of the labor force and labor opportunities in Chile. This centralization feature is widely recognized and remains a relevant issue to address at the policy level for various reasons, including the demographic, socioeconomic, and health inequities that exist 
in Chile across different areas of the country.

Variation in the country of origin of immigrant health workers living in Chile adds another layer of complexity to the patterns of migration, along with the wide range of their cultural backgrounds, which is likely to result in differences in immigrants' expectations and adaptation to Chile over time. Other relevant yet unmeasured variables, such as reasons for immigration, socioeconomic and health status prior to migration, adaptation to Chile after arrival, length of stay in the country, variations in legal status and contractual status, and experiences of stigma and discrimination, could be explored in future research.

The results of this study complement evidence from the significant amount of research that has been conducted on the "brain drain" phenomenon in Latin America in the past $(6,15-19)$. As shown in prior studies, migration patterns in the region are deeply connected with economic, social, and political dynamics at both the country and global level. This study is a first step toward understanding these dynamics in Chile.

\section{Conclusions}

While this study of immigrant health workers does not identify a significant "brain drain" to Chile, it does suggest that there are distinctive patterns of international immigration in the Latin American region. Future studies in Chile could confirm the validity of these results using a larger sample of immigrant health workers. A health worker survey, in particular, could help to disentangle many of the characteristics observed in this study. In addition, longitudinal analysis following immigrant health workers since before their arrival and throughout the migration process could contribute to a new perspective of the "brain drain" of health workers in the Latin American region.

Acknowledgments. The authors thank the Chilean Ministry of Social Development (MSD, formerly known as the Ministry of Planning or MIDEPLAN), for providing the 2009 CASEN survey dataset; Sebastian Farias and Ana Maria Veliz of the MSD, for their support; and all participants in the 2009 CASEN survey. The authors also thank three blinded peer reviewers for their contributions to this article.

\section{REFERENCES}

1. Martine G, Hakkert R, Guzman JM. Aspectos sociales de la migración internacional: consideraciones preliminares. Paper presented at the Simposio sobre Migración Internacional en las Américas, San José, Costa Rica, 4-6 September 2000. Available from: www.eclac. org/publicaciones/xml/2/8852/lcg2124P_5. pdf Accessed 21 November 2008.

2. Mejia A, Pizurki H, Royston E. Physician and nurse migration: analysis and policy implications. Report of a WHO study. Geneva: World Health Organization; 1979. Available from: www.who.int Accessed 3 December 2008.

3. Buchan J, Perfilieva G. Health worker migration in the European region: country case studies and policy implications. Copenhagen: Division of Country Support, World Health Organization Regional Office for Europe; 2006. Available from: www.euro.who.int Accessed 3 December 2010.

4. Schramm C. What do we know about international migration from the Middle East and North Africa? A migration literature review. Washington: World Bank Middle East and North Africa Region; 2006.

5. Docquier F, Marfouk A. Measuring the international mobility of skilled workers (19902000): release 1.0. Washington: World Bank; 2004. World Bank Policy Research Working Paper No. 3381. Available from: http:// econ.worldbank.org/external/default/ma in? pagePK=64165259\&theSitePK $=469382 \&$ piPK $=64165421 \&$ menuPK $=64166093 \&$ entit yID=000160016_20040922150619 Accessed 2 February 2009.

6. Özden Ç. Brain drain in Latin America. Paper presented at the Expert Group Meeting on International Migration and Development in Latin America and the Caribbean,
United Nations Secretariat, Mexico City, 30 November-2 December 2005. Available from: www.un.org/esa/population/meetings/ IttMigLAC/P10_WB-DECRG.pdf Accessed 2 February 2012.

7. Dumont JC, Martin JP, Spielvogel G. Women on the move: the neglected gender dimension of the brain drain. Bonn (Germany): Organisation for Economic Co-operation and Development; 2007. Available from: http:// www.ocde.fr/dataoecd /4/46/40232336.pdf Accessed 21 January 2009.

8. World Health Organization. WHO Global Code of Practice on the International Recruitment of Health Personnel. Geneva: WHO; 2011. Available from: www.who.int/hrh/ migration/code/practice/en/index.html Accessed 5 May 2011.

9. Cerna L. Policies and practices of highly skilled migration in times of the economic crisis. Geneva: International Labour Organization; 2010. Available from: www.ilo.org/public/english/ protection/migrant/download/imp/imp99. pdf Accessed 21 February 2012.

10. Cabieses B. The living conditions and health status of international immigrants in Chile: comparisons among international immigrants, and between them and the Chileanborn [PhD thesis]. York (England): University of York; 2011. Available from: http:/ / etheses. whiterose.ac.uk/1935/.

11. Alvarado IG, Sánchez H. Migration in Latin America and the Caribbean: a view from the ICFTU/ORIT. Geneva: International Labour Organization; 2002. Available from: http:// library.fes.de/pdf-files/gurn/00084.pdf Accessed 4 February 2009.

12. United Nations Educational, Scientific and Cultural Organization. Globalization and international migration in Latin America and the
Caribbean: trends and prospects for the 21st century. Final report on regional seminar in Santiago, Chile, 27-29 October 1998. Paris: UNESCO; 1999. Available from: http://unes doc.unesco.org/images / 0011/001185/ 118565Eo.pdf Accessed 4 February 2009.

13. Pellegrino A. Trends in international migration in Latin America and the Caribbean. Paris: UNESCO; 2000. Available from: http:/ / library.sau.edu/jpollitz/latam/immigration. pdf Accessed 4 February 2010.

14. Pellegrino A. Tendencias de la migración internacional en América Latina y el Caribe en la segunda mitad del siglo XX. In: Oteiza E, editor. Patrones migratorios internacionales en América Latina. Buenos Aires: Eudeba, Universidad de Buenos Aires; 2010. Pp.27-46.

15. Pellegrino A. La migración calificada en América Latina. Foreign Affairs Latinoamerica. 2008;8(2):15-26. Available from: http:/ / www. imprasc.net:29572/ArticulosdeInteres / Documents / Foreign\%20Affairs\%20Latino américa / 03\%20migracion\%20calificada.pdf Accessed 4 February 2009.

16. Pellegrino A. Skilled labour migration from developing countries: study on Argentina and Uruguay. Geneva: International Labour Organization; 2002. Available from: www. ilo.org/public/english/protection/migrant/ download/imp/imp58e.pdf Accessed 4 February 2012.

17. Oteiza E. Drenaje de cerebros: marco histórico y conceptual. In: Charum J, Meyer JB, editors. El nuevo nomadismo científico: la perspectiva latinoamericana. Bogotá: Escuela Superior de Administración Pública; 1998. Pp. 61-78.

18. Martinez-Pizarro J. Intraregional migration of skilled manpower. CEPAL Rev. 1993;(50): $127-46$. 
19. Mckee DL. Some specifics on the brain drain from the Andean region. Int Migr. 1983; 21(4):488-99.

20. Horn JJ. The medical "brain drain" and health priorities in Latin America. Int J Health Serv. 1977;7(3):425-42.

21. Carballo M, Divino JJ, Zeric D. Migration and health in the European Union. Trop Med Int Health. 1998;3(12):936-44.
22. Ministerio de Desarrollo Social (CL). CASEN 2006: Encuesta de Caracterización Socio-Económica Nacional. Documento metodológico. Santiago: MDS; 2006. Available from: www.mideplan.gob.cl/casen/pdf/meto dologia 2006.pdf Accessed 13 March 2011.

23. Ministerio de Desarrollo Social (CL). CASEN 2009: informe metodológico. Santiago: MDS; 2009. Available from: www.mideplan.gob.cl/ casen/pdf/metodologia_2009.pdf Accessed 13 March 2011

24. Arteaga O, Astorga I, Pinto AM. Desigualdades en la provisión de asistencia médica en el sector público de salud en Chile. Cad Saude Publica. 2002;18(4):1053-66.

Manuscript received on 7 June 2011. Revised version accepted for publication on 23 February 2012
RESUMEN

Inmigración de personal sanitario hacia Chile: ¿hay una "fuga de cerebros" hacia América Latina?
La mayoría de las investigaciones sobre el fenómeno de la "fuga de cerebros" (migración unidireccional de individuos sumamente capacitados y educados) se ha centrado en la migración desde países menos desarrollados hacia países muy desarrollados. Por consiguiente, la importancia de los patrones de migración hacia países de ingresos medios, como los de América Latina, está menos clara. El objetivo de este estudio fue describir las características clave de la "fuga de cerebros" internacional de personal sanitario hacia Chile para promover el análisis e investigaciones adicionales sobre este fenómeno en lo que respecta a América Latina. En el estudio se comparó al personal sanitario inmigrante residente en Chile, con el personal sanitario nacido en Chile y otros inmigrantes residentes en Chile utilizando un conjunto de datos cualitativos de todo el país (los resultados de la Encuesta de Caracterización Socioeconómica Nacional de Chile del 2009). Se incluyeron en los análisis variables demográficas, socioeconómicas y relacionadas con la salud, que fueron ponderadas según la población para obtener cálculos representativos a nivel nacional.

En el 2009, el personal sanitario conformado por inmigrantes representó 2,2\% del personal de salud y $2,6 \%$ de los inmigrantes residentes en el país. Aunque la mayoría del personal sanitario inmigrante tenía estudios universitarios, cerca de $25 \%$ tenía solamente educación secundaria o de menor nivel.

No hubo diferencia estadísticamente significativa entre la distribución del ingreso familiar del personal sanitario inmigrante y el del personal sanitario nacido en Chile. Una proporción significativamente mayor del grupo de inmigrantes informó no tener derecho a la provisión de atención de salud. Aunque los resultados de este estudio no indican que exista una "fuga de cerebros" internacional significativa de personal sanitario hacia Chile, señalan patrones característicos de migración dentro de América Latina. Los estudios futuros en Chile podrían confirmar la validez de estos resultados, mediante una muestra más grande de personal sanitario inmigrante.

Palabras clave Personal de salud; migración; América Latina; Chile. 